Chicago-Kent College of Law

Scholarly Commons @ IIT Chicago-Kent College of Law

All Faculty Scholarship

Faculty Scholarship

January 2009

\title{
Pirates of the Caribbean: The SEIU's Failed Bid in Puerto Rico
}

César F. Rosado Marzán

IIT Chicago-Kent College of Law, crosado@kentlaw.iit.edu

Follow this and additional works at: https://scholarship.kentlaw.iit.edu/fac_schol

Part of the Comparative and Foreign Law Commons, and the Labor and Employment Law Commons

\section{Recommended Citation}

César F. Rosado Marzán, Pirates of the Caribbean: The SEIU's Failed Bid in Puerto Rico, 12 WorkingUSA:

The J. of Lab. \& Soc'y. 235 (2009).

Available at: https://scholarship.kentlaw.iit.edu/fac_schol/514

This Article is brought to you for free and open access by the Faculty Scholarship at Scholarly Commons @ IIT Chicago-Kent College of Law. It has been accepted for inclusion in All Faculty Scholarship by an authorized administrator of Scholarly Commons @ IIT Chicago-Kent College of Law. For more information, please contact jwenger@kentlaw.iit.edu, ebarney@kentlaw.iit.edu. 


\title{
PIRATES OF THE CARIBBEAN: SEIU'S FAILED BID IN PUERTO RICO
}

\author{
César F. Rosado Marzán
}

\begin{abstract}
In October of 2008, the Service Employees International Union (SEIU) failed to obtain majority support to represent a 40,000-member bargaining unit of public school teachers in Puerto Rico even though it had most of the odds stacked in its favor: a huge war chest, a decertified and bankrupt rival, and the Puerto Rican government qua employer's neutrality, if not outright support. The Federación de Maestros de Puerto Rico, the SEIU's rival, campaigned against the SEIU's bid for exclusive representation by focusing on rank-andfile mobilization and a message against raiding by a "colonial" union. The event showed that even progressive and successful unions such as the SEIU are not immune to oligarchic tendencies and may raid other unions in pursuit of money and power. Strategies that combine more democratic, bottom-up mobilization, including, in the case of Puerto Rico, strengthening the long-established tradition of minority unionism, could dampen future oligarchic tendencies, buttress industrial democracy, and create better coexistence between trade union organizations. To move forward, especially given the global crisis that has befallen us, unions need to start acting in the most principled of ways and expressing solidarity in the deepest manners.
\end{abstract}

The year 2008 was among the grimmest of years for workers worldwide and 2009 will be worse. Neither was 2008 a stellar year for the Service Employees International Union (SEIU), a union otherwise recognized for its organizational and political successes. While the U.S. was deep in the presidential campaign debating the causes and possible solutions to the global economic crisis, we learned that the SEIU was embroiled in fights against one of its largest locals, United Healthcare Workers West (UHW). The schism was related to whether or not the SEIU could divide UHW into two locals, one representing the nursing home/home health aid workers and another one for the rest. A less commented upon but equally important story was the SEIU's fight in the U.S. "Commonwealth" qua colony of Puerto Rico against the Federación de Maestros de Puerto Rico (FMPR), the main teachers' union of that Caribbean island. There, the interunion spat was related to a union election campaign where SEIU supported a new affiliate to its structure, the Asociación de Maestros-Sindicato Puertorriqueño de Maestros (AMPR-SPM), or the Association of TeachersPuerto Rican Teachers Union, against the FMPR. Even though in January of 2009 SEIU's international union was successful in splitting UHW and placing it under trusteeship, in October of 2008 SEIU suffered a dramatic setback when it 
lost the union elections to represent 40,000 Puerto Rican teachers. This loss occurred in spite of the fact that the SEIU local ran unopposed in the official ballot, had an enormous war chest, had scores of imported foot soldiers from the U.S. to campaign for the union, and even had the blessing of the employer, the Puerto Rican government. ${ }^{1}$

The FMPR, sectors of the Puerto Rican left, and others sympathetic to Puerto Rico's struggle for national self-determination saw the SEIU's loss as a victory against union "imperialism" and "colonialism." Some advocates of the labor colonialism or imperialism concept argue that the SEIU, and any other U.S.-based international union, has an explicit or hidden agenda to keep Puerto Rico subjugated to U.S. colonialism and its imperialist project. ${ }^{2}$ However, this hard-line, anti-imperialist perspective is not backed by evidence and fails to appreciate the reasons underlying the SEIU's interest in Puerto Rico. Here I argue that SEIU's bid to represent Puerto Rican teachers was motivated by old-fashioned "oligarchic" concerns (cf. Michels 1962), including deriving a new source of union dues and consolidating political power in Puerto Rico. The effects of such oligarchic expansion could be termed "colonial" as they include the Americanization of Puerto Rican labor institutions by further extending U.S.based international union structures and cementing exclusive representation privileges to labor unions, an institutional arrangement which, although exists in different forms in foreign jurisdictions, is predominantly American (Summers 1998). Finally, the article concludes by arguing that the SEIU's failed bid to represent the teachers, as other interunion conflicts, calls for U.S. unions to adopt more bottom-up practices firmly based on workers' lived experiences, and in this fashion, create organizations that are more relevant to the needs of workers, serve as an instrument to unite the working class, and curb the officialdom's tendencies to engage in destructive power plays. Adopting more bottom-up strategies does not mean that unions should abandon all top-down strategies and activities. It just calls for a more balanced approach. In the case of Puerto Rico, this can mean that unions should try to pause their incessant pursuit of exclusive representation and consider reinforcing the long-standing practice of minority unionism to expand industrial democracy and working class organization while at the same time diminish incentives for union raiding.

\section{Unions in Puerto Rico, 1898-Present}

U.S. union presence in Puerto Rico can be traced almost to the day in which victorious U.S. troops fighting in the Hispanic-American War marched into the southern Puerto Rican port of Guánica in 1898. At first, American union presence in Puerto Rico was indirect. Santiago Iglesias Pantín, Puerto Rico's most prominent labor leader in the late nineteenth and early twentieth century, sought economic aid from Samuel Gompers' American Federation of Labor (AFL) to organize Puerto Rican workers, aid which Gompers provided to promote better wages and working conditions in Puerto Rico and limit Puerto Rican migration to the U.S. (Galvin 1979, 56; García and Quintero Rivera 1984, 
37-9). Notwithstanding Gompers' aid and Puerto Rican unions' formal association with the AFL, Puerto Rico developed an autochthonous labor movement with little resemblance to its U.S., "business unionism" counterpart. By 1915, Santiago Iglesias' federation, the Federación Libre de Trabajadores (FLT), had led militant strikes in Puerto Rico's cane fields, where most Puerto Rican workers labored. The FLT also created the Socialist Party in 1915, with the feared "torch" as its symbol. The torch, usually recognized as a symbol of truth and liberty, had a different meaning in Puerto Rico, because it was the main tool used by worker activists to char sugarcane when their bosses refused to bargain with the workers. The Socialist Party also ran candidates, some of which won the mayoral office of many cities and towns of Puerto Rico (García and Quintero Rivera 1984, chapter 5).

In the early 1930s, the FLT and the Socialist Party took a more conservative line and allied themselves with the conservative Partido Republicano, or Republican Party, the party of the landowners and sugar barons. ${ }^{3}$ As a result, Socialist and FLT left-wing cadres and some members of the Nationalist Party, a radical anti-imperialist and pro-independence political formation, founded a Communist current that was later responsible for both the establishment of the proSoviet, Communist Party of Puerto Rico and the creation of the Confederación General de Trabajadores (CGT), a labor union federation organized under the lines of "industrial unionism" of the American Congress of Industrial Organizations. The FLT and the Socialist Party continued to operate, but were in rapid decline, both in terms of membership and overall influence in Puerto Rican society and politics. Around the same time, the Partido Popular Democrático, or the PPD, was also organized by Luis Muñoz Marín and others. Initially, the PPD had a populist program for "bread, land and liberty" and for Puerto Rican political independence. The CGT supported the fledgling populares. However, by the 1940s, the PPD attenuated its program, advocating for mere local autonomy for Puerto Rico other than full-blown independence and for an export-based development program more in line with U.S. interests. ${ }^{4}$ It also made a call to the labor movement and other civil society groups to join the party. The CGT split into a popular faction that became an active part of the PPD. A more independent and militant faction of the CGT split from the labor organization as the PPD became more powerful and more conservative. Eventually, the non-PPD faction was repressed by the government and McCarthyism (Ayala and Bernabe 2007, chapter 7; García and Quintero Rivera 1984, 135-6).

By mid-century, the PPD had become a hegemonic party in Puerto Rico, winning consecutive elections with much more than 50 percent of the vote from 1944 until 1968. Puerto Rico also became a preferred site for runaway industry, given the island's free trade relationship with the U.S., federal tax exemptions, and low wages.

When the AFL-CIO was created in 1954, the federation was at first uncomfortable with Puerto Rico's "tax haven" status, which was bleeding many U.S. union shops in the mainland. However, the AFL-CIO eventually came to support the Commonwealth status for Puerto Rico and its economic model as 
long as the government of Puerto Rico did not oppose its unions' organizing drives in the island (Galvin 1979, 157-61; Rosado Marzán 2005). In this manner, the AFL-CIO became a partner of the PPD, just as the moderate wing of the CGT became in the previous decade.

It was not until the late 1960s when the PPD lost its first elections against the pro-statehood ${ }^{5}$ Partido Nuevo Progresista, or the New Progressive Party, and when a new crop of young, radicalized labor leaders came to the fore, that independent labor organizations began to take renewed importance in Puerto Rico (García and Quintero Rivera 1984, 140-2). Because most public sector employees did not have collective bargaining rights under Puerto Rican law, many of these independent labor organizations were "bona fide associations," or minority unions with no formal collective bargaining rights. Nevertheless, thousands of public sector workers, including teachers, joined them and undertook militant strategies to pressure for concessions from the government-employer.

As more fully detailed in a former article (Rosado Marzán 2007), U.S.-based unions made a comeback in Puerto Rico in the late 1990s when the government of Puerto Rico granted public sector labor unions majority representation rights. A 1998 public sector labor law provided a new opportunity to U.S.-based unions to return to Puerto Rico, as it gave them a more familiar, if not profitable, institutional framework to represent workers-exclusive representation.

\section{The FMPR}

Some bona fide associations did not disband with the new 1998 public sector labor law. Fearing that they would be displaced by other labor organizations, some bona fide associations such as the FMPR decided to reorganize themselves as workers' exclusive representatives under the new law. At that time, the FMPR was affiliated with the American Federation of Teachers (AFT), its parent international union since the 1960s. The international union provided monetary and human resources to help the local union campaign and win union elections in 1998. At that time, the FMPR won the union elections against the AMPR. Once it became the exclusive representative of all public school teachers, the FMPR catapulted to new heights of importance in Puerto Rican industrial relations.

In 2004, the FMPR disaffiliated with the AFT as a result of several events. First, in 2003, a left-wing caucus of the union, Compromiso, Democracia y Militancia (CODEMI) - Commitment, Democracy and Militancy—defeated the incumbent leadership in labor union elections after the incumbent leadership was involved in a number of scandals, including the bankruptcy of the union's health insurance fund. The CODEMI argued for disaffiliation with the AFT not only because of the prior leadership's mishandling of the union, but also because the international union was increasing its per capita union dues to the FMPR while teachers' salaries remained stagnant at about $\$ 20,000$. The CODEMI also argued that while the teachers suffered economic deprivation and low wages, 
Washington-based officers of the international union made six-figure salaries. Finally, the CODEMI also wanted a divorce from the AFT to pursue a different strategy in its actions against the employer based not on lobbying government leaders, as the AFT preferred, but on mobilizing the rank and file. After putting the issue before an assembly of delegates and, thereafter, to the entire membership in a referendum, the vote for disaffiliation triumphed overwhelmingly, and the FMPR disaffiliated from the AFT. The AFT tried to challenge the disaffiliation in the courts and by placing the FMPR into trusteeship, but both tactics failed.

\section{SEIU versus FMPR}

Struggles between the AMPR, the parent union of the SPM, and the FMPR have deep roots that surpass any SEIU influence or involvement in Puerto Rico. In 1913, more than fifty years before the FMPR was formed, teachers and other educators in Puerto Rico created the AMPR as a professional and mutual aid society (Ayala and Bernabe 2007, 78). Although it has not always represented teachers' interests as employees for it has had a thick layer of management personnel as members and leaders, it did promote important initiatives, such as the elimination of mandatory, English-only language instruction for all public school students in Puerto Rico. Mandatory, English-only language instruction was clearly a colonial policy of the former U.S.-appointed governors of the island with no other aim but to strip Puerto Ricans of their Hispanic culture (See Ayala and Bernabe 2007, 75-8). The policy failed for many reasons, including the fact that teachers, being Puerto Ricans themselves and having no English language skills, did not, and could not, implement it.

In the 1940s, the AMPR joined the PPD's populist political project and functioned as the teachers' wing of the party in an almost corporatist framework. The AMPR became a highly prominent organization, but some teachers sustained that the AMPR provided no independent voice for teachers as a result of its affiliation with the PPD. In the 1960s, these disaffected teachers formed the FMPR as a rival institution.

In recent years, the AMPR created the SPM to challenge the FMPR in union elections. The AMPR created the SPM to challenge the teachers because the AMPR's leadership and membership includes public school directors and other supervisory personnel which, under Puerto Rican law, as most labor laws in U.S. jurisdictions, cannot be members of a union's bargaining unit. Moreover, knowing that the FMPR would be a difficult rival to beat, AMPR-SPM also affiliated with the SEIU in 2008 to buttress its resources for the upcoming union elections.

By the time the AMPR-SPM affiliated with the SEIU, the U.S.-based international union had two locals in Puerto Rico which, together, had about 30,000 members out of a total of about 140,000 members of labor organizations in Puerto Rico. If the SEIU would have won the elections, it 
would have represented about 70,000 workers in Puerto Rico, or about half of all members of labor organizations in the island, making the SEIU the numerically most important labor institution in Puerto Rico. While a victory in those union elections would have been a major turning point for AMPR, which for more than ten years had been trying to unseat the FMPR as the exclusive representative of the teachers, it would have been nothing short of a political bonanza for the SEIU, which could then speak on behalf of almost a majority of all labor organization members in Puerto Rico.

\section{FMPR's Illegal Strike and Decertification}

While the AMPR-SPM, now affiliated with the SEIU, prepared to challenge the FMPR in union elections, the FMPR was negotiating a new collective bargaining agreement with the management, the Puerto Rico Department of Education (DOE). The teachers had been without a contract for three years, and in late 2007, the FMPR's members' plenary assembly, attended by tens of thousands of members, voted in favor of a resolution to implement a strike at any time the leadership of the union found it proper. The members' assembly provided such authority to the leadership even though the 1998 public sector labor law, which governed the affairs of the FMPR, made strikes illegal. The union would face decertification if it engaged in a strike.

Without the FMPR yet calling for a strike, the Puerto Rico DOE filed an unfair labor practice charge against the union for voting in favor of a strike. The Puerto Rico Public Service Commission (Commission), the agency that administers the 1998 public sector law and adjudicates such charges, decided the charge in favor of the DOE, issued a complaint against the FMPR, and decertified the largest union in Puerto Rico. At that point, the DOE announced it would no longer bargain with the FMPR because the union had been decertified.

Already into the New Year, the FMPR challenged the decertification order in the Puerto Rico Court of Appeals. Based on policy grounds to protect the public interest, the Court made an interim decision in favor of the union and called on the parties to sit at the negotiating table and reach an agreement. The parties started to bargain again, and the DOE made a number of important concessions, but not enough to satisfy the FMPR's leadership.

In February of 2008, the FMPR leadership implemented the strike. ${ }^{6}$ With the strike now a reality, the DOE filed another unfair labor practice charge at the Commission. The FMPR was, again, decertified, but this time, having clearly violated the law, remained decertified and could no longer officially represent Puerto Rican teachers. Moreover, under the 1998 public sector law, any labor organization found in violation of the no-strike provision could not run in union elections for at least five years. Therefore, the decertification of the FMPR cleared the way for the AMPR-SPM to run unopposed in new elections. 


\section{Officially Unopposed in the Ballot, SEIU Still Lost the Elections}

Union elections for the representation of public school teachers took place from October 1 to 16 of 2008. The only options in the ballot were for the AMPR-SPM, the "Yes" option, and the "No" option for no union representation. Because the FMPR could not participate in the elections, it called on teachers to vote "No." The FMPR was clearly outspent by the SEIU during the elections. Although denied by the SEIU, the FMPR claims the SEIU spent as much as $\$ 20$ million in the campaign ${ }^{7}$ while FMPR spent a scrawny $\$ 65,000$ to campaign for the "No" option. However, the FMPR was not outgunned because the FMPR mobilized thousands of rank-and-file teachers in support of the "No" option. The "No" option won by a large margin-18,125 against 14,675 "Yes" votes. Perhaps most impressive was the 95 percent voter participation rate that would embarrass most local union referenda in the U.S., where union members seldom participate.

After the elections, the FMPR declared that it had won against the "dues suckers," "company union," and "labor colonialists" of the AMPR-SPM (Torres Torres 2008). By that time, the FMPR had reorganized itself as a bona fide association and counted with 11,000 members who voluntarily joined the FMPR, and requested the DOE to deduct membership fees for the union (Torres Torres 2008). These union elections and the reorganization of the FMPR proved that the FMPR, even as a minority union, remained an impressive social force that not even spectacular "top-down" campaigns by U.S.-based unions and government opposition could defeat.

\section{Oligarchic Tendencies of Organizations}

Labor "imperialism" and "colonialism" are terms generally associated with the Leninist left and related national liberation movements. Lenin developed a concept of the "labor aristocracy," which then has been extended into notions of labor imperialism and colonialism. According to Lenin, developed nations, which are dominant centers of capitalism (the "imperialists"), extend to underdeveloped countries to control markets of raw materials and open other markets to sell their excess manufactured goods. In this manner, imperialists "buy cheap and sell dear." This relationship of unequal exchange stunts the capacity of developing countries to develop economically, tying them to dependent economic relations with imperialist countries, while imperialist countries make "super-profits." Moreover, workers in the imperialist countries, believing that their higher standard of living depends on the continued subjugation of the colonies to their imperialist nation, collaborate in the processes of subjugation and colonialism by supporting their national political forces, turning those workers into a "labor aristocracy" and agents of imperialism (Lenin 1939, 13-4).

Many actions of the AFL-CIO during the Cold War, which included orchestrating coups against left-wing governments, could fit this theory of labor imperialism or colonialism (See Buhle 1999, 136-45). However, there is not an 
ounce of evidence that would sustain that the SEIU supports Puerto Rican colonialism or its submission to the U.S. imperialist project. In fact, the SEIU officially recognizes Puerto Rico's right of self-determination and formally considers the inhabitants of the U.S. "Commonwealth" as a distinct nation. In fact, visible SEIU officers at both the international and local levels started their activist careers in Puerto Rican socialist and national liberation organizations such as the Cuban-inspired (and now defunct) Partido Socialista Puertorriqueño.

Moreover, we must be reminded that the SEIU did not create the AMPRSPM to dominate Puerto Rican unionism. The AMPR has almost a one hundred-year-old history in Puerto Rico, and its collective bargaining arm, SPM, voluntarily affiliated with the SEIU. The AMPR's rivalry with the FMPR goes back to the 1960s, much before the SEIU was even a known entity in Puerto Rico. The SEIU could be blamed for getting involved in a street fight it did not initiate, lured by the prospects of power and money, but not for causing the current fight between rival teachers' unions.

Nevertheless, there is another way in which the SEIU's actions in Puerto Rico can be considered "colonial," which we should lay out in the open for discussion. One of the giants of twentieth century social science, Joseph Schumpeter (1991), arguing against the Leninist conception of imperialism, sustained that imperialism was a process of institutional expansion of bureaucratic organization motivated simply by pursuit of power. In this manner, imperialism is "objectless," with no inherent or underlying class interest driving the institutional expansion, in contrast with the Leninist view where class interests are the locus of imperialism.

Schumpeter's view of imperialism, when extended to the phenomenon of organizational diffusion, shares common ground with Robert Michels' theory of "oligarchic tendencies of organizations" (Michels 1962). For Michels, the oneparty state structure of labor unions and the concentration of union resources on incumbents make the organizations inherently undemocratic, eventually uninterested in pursuing their substantive goals and becoming increasingly involved in maintaining and consolidating their power. Hence, a Michels-Schumpeter driven theory of union expansion from core to peripheral areas, or from the U.S. to Puerto Rico, would sustain that U.S. unions extend to Puerto Rico to pursue nothing other than greater power and resources, a likely explanation given that the 40,000-member bargaining unit of the FMPR would not only have provided a hefty and steady stream of dues moneys to the SEIU, but also would have helped that international union consolidate itself as the most important union in Puerto Rico.

\section{Conclusion}

The SEIU's setbacks in Puerto Rico, as the situation with UHW, may simply be exceptions to the rule, blemishes in an overall landscape of progress by that international union and, generally, U.S. unions. For one, Barack Obama, supported universally by the labor movement, won the elections and has promised 
to sign the Employee Free Choice Act (EFCA) when passed by Congress. The EFCA would apply to Puerto Rico, just as the rest of the Federal labor laws, and will help promote unionism in the island. Moreover, union membership in the U.S. increased in 2008 by more than 428,000 members, which provides evidence of some labor resurgence even without the EFCA (Bureau of Labor Statistics 2009). Finally, many prominent union leaders are speaking about fusing the now divided AFL-CIO and Change to Win unions into a new federation. This is progress.

However, as this essay goes to press, not only have there been internal problems in the SEIU, but also leaders of one of the Change to Win unions, UNITE HERE, are also involved in inner struggles, threatening to break the union into its former UNITE and HERE segments, or displacing one of the two factions from the union's leadership (Meyerson 2009). Moreover, there is concern in labor circles that Congress will not pass the EFCA and nothing will get to Obama's desk for approval. What then?

But most importantly, in the U.S., more than 1.5 million workers lost their jobs from November of 2008 through January of 2009. In Puerto Rico, unemployment figures have seldom risen above the double digits since the 1960s, and it currently stands at about 13 percent, or about twice that of the U.S. To make matters much worse in an economy that has already lost thousands of private sector jobs, on March 3, 2009, the Governor of Puerto Rico, Luis Fortuño, announced that the government would have to axe about 30,000 employeesabout 10 percent of the total number of government employees-in order to balance the budget and stop credit agencies from degrading Puerto Rico's bonds to "junk" status. In a country of roughly four million inhabitants, where only about 1.3 million are in the economically active population, 30,000 job cuts blow a large hole on an already tattered economic structure. Moreover, with 1 percent-yes, "one percent"-union density in manufacturing and commerce, and 3 percent in the services sector-a category that includes public sector employees (Negociado de Estadísticas del Trabajo 2005)—we can confidently say that private sector unions are essentially nonexistent in Puerto Rico. Employers won that fight.

With such a negative organizational landscape in Puerto Rico, a less than desirable one in the U.S., and with a deep economic crisis in our throes, infighting by the union officialdom seems almost comical. Of course, the problem is that none of these is really funny, at least as far as workers are concerned. Notwithstanding the fact that most workers desire to be in a union and have health care, pension benefits, and "for cause" termination as cornerstones of their employment, most workers simply do not engage in collective workplace activism. Hope, if anywhere, seems to be placed on individual actions, the government, or God.

This can change, but it will require a multipronged strategy that combines not only top-down tactics, such as pushing for the EFCA and political lobbying, but also massive efforts to reignite bottom-up mobilization to levels significantly much grander than ever attempted in recent labor history. If banks need a 
multitrillion dollar bailout to recover from their crisis, unions need millions of new worker activists to be involved in the lives of their organizations to make them more relevant and influential players in our political economy. For these ends, unions have to provide workers with real possibilities to attain authoritative positions in their organizations and put significant resources at their disposal to combat employers at the level of production and in their communities. In the U.S., this has to mean stopping internal fights, focusing energies both on the workplace, local and state levels and on Washington, but not merely through lobbying. One key area where organizing will matter will be among the unemployed, who already reach the millions and could serve as a powerful group of organized worker-citizens to stir U.S. politics leftward, if that energy is organized and channeled appropriately.

In Puerto Rico, U.S.-based solidarity has to mean that unions need to stop the practice of putting millions of dollars of their members' dues into union election campaigns that resemble old-fashioned "raids" and channel resources into activities that truly organize and unite the working class. U.S. union members' dues could be spent on organizing private sector workers, itself the most important item that labor should have in its agenda in Puerto Rico, as well as the unemployed. Resources can also be committed to build horizontal alliances with existing unions and other sectors of civil society, such as the amalgam of community groups challenging everything from mass layoffs to the acts and corruption of unscrupulous construction companies that degrade the Caribbean island's environment. Moreover, rather than challenging existing unions with clean records and high levels of prestige, such as the FMPR, and getting involved in their street fights, U.S. unions in Puerto Rico should be serving as third party mediators of such conflicts, functioning as agents of unity. With the economic crisis and massive layoffs affecting so many working families in Puerto Rico, anything short of the most principled solidarity by U.S. unions will be seen by many in the progressive community as tantamount to betrayal.

U.S.-based unions could also channel resources to reinforce the island's autochthonous and long-standing practice of minority unionism, which led to the organization of the public sector in the 1960s and which remains alive today even after the Puerto Rican government and U.S.-based unions tried to totally replace it with exclusive representation unionism. Even in the National Labor Relations Act's context, recognition and certification of minority unions have been proposed as a way to bring back industrial democracy to the American workplace (Morris 2005). In Puerto Rico, a fortified version of minority unionism in the traditional agencies of the public sector, already a labor institution, could aim for workers' right to bargain with their employers once they organize themselves into a bona fide association, even without majority support. Given that exclusive representation in the public sector has almost invariably led to raiding and has not increased labor union density at all, unions in Puerto Rico should even tactically consider abandoning exclusive representation for public sector employees in the traditional government agencies. Pressuring the government to recognize and bargain with minority unions will not only help 
increase union density, and strengthen union and industrial democracy, but could also dampen the raids between unions. To close the representation gap that will result from member-only agreements, the government could extend the wages and terms and conditions of employment of union members to nonunion employees, as it occurs in France, Germany and other international jurisdictions.

Strengthening minority unionism is a policy item that all unions in Puerto Rico, both U.S.-based and independent, would benefit from. However, no one, on either side of the fence, has ever discussed or proposed it as a legislative initiative in Puerto Rico. Is this thinking too much outside the box? But is this not precisely what we need to be doing today in light of labor's organizational crisis and the economic hecatomb that lies before us?

It is almost ironic that in spite of the millions of dollars that unions commit to "research" and to draw up complex union strategies that include litigation, having a say in capital investment bodies and corporate boards, perhaps the union action that most caught the attention of the American public in recent years was this winter's improvised takeover of the Republic Windows factory of Chicago by its workers after the factory announced it would shut down without paying severance pay or providing sixty-day notice of the plant's closing to the workers. The workers' direct action put not only the manufacturer on the spotlight, but also Bank of America, which, even though received billions of public bailout funds, would not provide a relatively small credit line to the manufacturer to pay workers the moneys it owed to them. These workers' actions eventually led them to obtain their severance pay and even attracted the attention of a "green" manufacturing company in California, which is now interested in buying the Republic Windows factory to reopen it and reemploy the workers (Streit 2009). These actions by flesh-and-blood workers are the kinds of events that put positive, national and international attention on the labor movement in a way that inspires others to take workplace activism as an important call for their own benefit and the public good. This is the real "stuff" of unions.

Especially in light of the global crisis and tragic internal strife faced by unions, perhaps it is time to pause and refocus our energies. In these times, our goals should be to act in the most principled of ways, open labor union structures to all workers, and build and provide the required organizational resources so that the working class can successfully stir history in a direction that strengthens it. This is what solidarity is all about.

César F. Rosado Marzán, JD, PhD, is Assistant Professor of Law at ChicagoKent College of Law, Illinois Institute of Technology. Prior to starting his academic career in the fall of 2008, he was an attorney in Puerto Rico and New York where he represented labor unions and employees. His $\mathrm{PhD}$ dissertation focused on the role of U.S.-based unions in organizing workers in Puerto Rico during the second half of the twentieth century. Address correspondence to César F. Rosado Marzán, Chicago-Kent College of Law, Illinois Institute of Technology, 565 West Adams Street, Chicago, IL 60661-3691. Telephone: 312906-5278. Fax: 312-906-5280. E-mail: crosado@kentlaw.edu 


\section{Notes}

1. The Governor of Puerto Rico, Anibal Acevedo Vilá, at the time also President of the Popular Democratic Party (known as the "PPD," its acronym in Spanish) and Dennis Rivera, an influential leader of the SEIU, directly involved in the SEIU's bid to represent Puerto Rican teachers, were known to be in friendly relations (González 2008). Meanwhile, the FMPR alleged that the government of Puerto Rico was stalling in the collective bargaining negotiations with the union, to the point of leaving all 40,000 teachers without a contract for three years.

2. This idea is generally voiced by some nationalists in public debates, among them independent union leader Luis Pedraza Leduc (Rosado Marzán 2005, 109).

3. Reasons for the FLT and the Socialist Party's turn to the right were complicated. For a historical analysis, see Galvin (1979, chapter 6).

4. The PPD promoted the current "Commonwealth" status of Puerto Rico, a territorial arrangement with the U.S. which, although still made Puerto Rico subject to the U.S. territorial clause and Congress' plenary powers, provided some self-rule for Puerto Rico backed by fiscal autonomy for the island and Federal tax breaks to promote U.S. investment.

5. "Pro-statehood" in Puerto Rico refers to the political tendency that favors Puerto Rico's annexation to the U.S. as the fifty-first state of the union.

6. According to the FMPR's leadership, the strike was democratically debated at every public school. It was finally voted in favor by a members' assembly. Nevertheless, the leadership's decision to implement the strike vote in February of 2008 was criticized by labor union rivals, such as the SEIU's leaders in Puerto Rico, Roberto Pagán and Aida Díaz, as well as labor union figures friendly to the FMPR, such as labor lawyer Alejandro Torres Rivera. According to Torres Rivera, there was no tactical need to call for a strike at a moment when the DOE was acting defensively and making concessions (Torres Rivera 2009). The SEIU leadership harped on the FMPR's likely ill-conceived decision to implement the strike vote as evidence that the leadership was not serious about representing teachers but, rather, was motivated by hidden political agendas. Nevertheless, even this point did not persuade enough teachers to provide the SEIU to give the U.S.-based union exclusive representation rights over Puerto Rican teachers.

7. The SEIU local leadership in Puerto Rico denies that the international union spent $\$ 20$ million in the campaign, but neither could it confirm a different number. The SEIU campaign did count with expensive prime-time television commercials, colored full-page newspaper advertisements, and huge billboard signs in Puerto Rico's main highways, among other propaganda.

8. However, as Post (2006) has argued, the concept of a labor aristocracy dates back at least to Fredrick Engels in his letters to Karl Marx.

\section{Acknowledgment}

The author thanks his research assistant, Elizabeth Koziol, for her help proofreading this essay.

\section{References}

Ayala, C., and R. Bernabe. 2007. Puerto Rico in the American century. Chapel Hill: University of North Carolina Press.

Buhle, P. 1999. Taking care of business. New York: Monthly Review Press.

Bureau of Labor Statistics. 2009. Union members summary. http://www.bls.gov/news.release/union2.nr0.htm (accessed February 13, 2009).

Galvin, M. 1979. The organized labor movement in Puerto Rico. Rutherford, Madison, and Teaneck, NJ: Fairleigh Dickinson University Press.

García, G., and A. Quintero Rivera. 1984. Breve Historia del Movimiento Obrero Puertorriqueño. San Juan, Puerto Rico: Ediciones Huracán.

González, J. 2008. New York labor leader Dennis Rivera in shady Puerto Rico union deal. New York Daily News, March 8. http://www.nydailynews.com/news/2008/02/29/2008-02-29_new_york_labor_leader_dennis_ rivera_in_s.html (accessed February 11, 2009). 
Lenin, V. I. 1939. Imperialism, the highest state of capitalism. New York: International Publishers.

Meyerson, H. 2009. Labor's real fight. Los Angeles Times, February 1. http://www.latimes.com/news/opinion/ commentary/la-oe-meyerson1-2009feb01,0,1206299.story (accessed February 13, 2009).

Michels, R. 1962. Political parties. New York: Free Press.

Morris, C. J. 2005. The Blue Eagle at Work. Ithaca: Cornell University Press.

Negociado de Estadísticas del Trabajo. 2005. Estadísticas de Unionados. May. Departamento del Trabajo y Recursos Humanos de Puerto Rico, http://tendenciaspr.uprrp.edu/trabajo/Unionados_2005.pdf (Accessed February 13, 2009).

Post, C. 2006. The labor aristocracy myth. International Viewpoint, http://www.internationalviewpoint.org/ spip.php?article1110\#nb2 (accessed February 13, 2009).

Rosado Marzán, C. F. 2005. Dependent unionism. PhD dissertation. Princeton, NJ: Department of Sociology, Princeton University.

— 2007. Solidarity or colonialism? The polemic of "Labor Colonialism" in Puerto Rico. WorkingUSA 10:287-99.

Schumpeter, J. 1991. The sociology of imperialisms. In The economics and sociology of capitalism, ed. R. Swedberg, 141-219. Princeton, NJ: Princeton University Press.

Streit, M. 2009. Republic may have new owner, union says. Chicago Business, January 14. http:// www.chicagobusiness.com/cgi-bin/news.pl?id=32611 (accessed February 13, 2009).

Summers, C. 1998. Exclusive representation: A comparative inquiry into a "Unique" American principle. Comparative Labor Law and Policy fournal 20:47-70.

Torres Rivera, A. 2009. Una breve reflexión al pasado y el futuro del movimiento obrero. Claridad, December $25-31,16-7$.

Torres Torres, L. A. 2008. Aragunde Nunca Más. Páginas Sindicales, October, http://www.fmprlucha.org/ federado/pagsindoctubre2008.pdf (accessed February 12, 2008). 